\title{
Autosomal recessive spastic paraplegia type 39
}

INSERM

\section{Source}

INSERM. (1999). Orphanet: an online rare disease and orphan drug data base. Autosomal recessive spastic paraplegia type 39. ORPHA:139480

This syndrome is characterised by progressive spastic paraplegia and distal muscle wasting. 